\title{
流水の蛇行及び流路形態に対する境界の効果 \\ Boundary Effects on Meandering Stream and RIver Morphology
}

\author{
金沢工業大学 正 員 中 川 武 夫 \\ 名古屋大学学生員堀田 正 史
}

\section{1. はじめに}

流路自体が蛇行をしていればその流路に沿って流れる水が蛇行するととは自明の理であるが、逆に流水が 蛇行するためには流路が蛇行をしているととは必ずしも必要ではない。ここて、流水の蛇行とは藤芳(1949) が定嶬した流心の水平振動と同義である。足立（1967）は重力作用のみによって流れている直線流路内の水 がある条件下で蛇行する事実に着目し、流水内に常に存在すると考えられる微小じよう乱こそが流水の蛇行 素因と考え、流水蛇行に関する理論展開を行なった。これに対して著者らは微小じよう乱以外により実体的 な流水の蛇行素因が存在するに䕗いないという予測加ら流水と流路境界之の間の干涉機構の中に流水の蛇行 素因が潜んでいるとする仮説をうちたてた。著者ら（1981）は既に流水が蛇行するためには、流路壁面の摩 擦抗力の流路幅方向への分布が重要な役割を果し、流路床中央部での摩擦抗力が、より外側の流路壁面の摩 擦抗力より大きいととが必要であるというとの仮説を支持する示唆をえている。

本論文は、上記の仮説の検証のための一段階として流路壁面の境界条件の流路幅方向への変化が流路内の 流水蛇行及び流路形態にいかなる影锌を与えるかを明らかにするととを意四したものである。

\section{2. 実駼置及び実験方法}

実検に使用した蛇行水路の概要をFig. 1 亿示す。水路は長さ $25 m$ 、幅 $2 m$ のモルタル製である。本実駼で は、水路上流端加 $5 \mathrm{~m}$ の区間を除く水路沫 全体に厚さ約 $30 \mathrm{~cm}$ の砂を敷きつめたのち、砂面勾配設定装置で まず水平距離 $12 m$ の区間を一定勾配 $\frac{1}{100}$ の砂面に整地し、この傾斜砂面に続く水平距離 $8 \mathrm{~m}$ の区間を水平砂 面とした。続いて、水路中央の砂層に一定断面の初期流路を設定した。こてでは、一定勾配の砂周区間のみ を実诶の対象とした。

水路内への水の供給は高水槽と水路との間の水頭差による。なお、高水槽と水路との間はパイプで連結さ れ、パイプ内の流量はパイブ内に取り付けられた電磁流量計により計測された。水路内へ运びかれた水はま す湛水部で流勢を止められたのち、流路入口部での流水の急縮に伴なう乱れを抑えるために設りられた流路 幅が漸煘する砂でできた導入流路を経て実臥 流路内へ流入するととになる。流路内を流れる水は流路壁の砂 の浸食、運搬及び堆積を繰り返しつつ水路下流端に達し㷌還水路を通り低水槽に魚る。

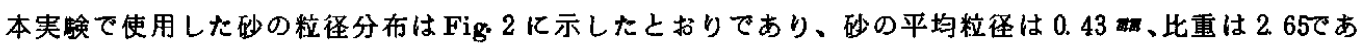
った。

Fig. 3 には、ことでの 4 㮔類の実騃でとの初期流路の形状、寸法及び境界条件を示した。また、実験 1、2、 3 そして 4 の設定流量はそれぞれ、0.50 ( $\ell / \mathrm{s}) 、 0.70(\ell / \mathrm{s}) 、 0.55(\ell / \mathrm{s})$ そして0.6 $(\ell / \mathrm{s})$ であった。

実験においては、流水挙動及び流路形態の写真撮影に加えて、Table1に揭げた諸量の測定を実験の前、中、

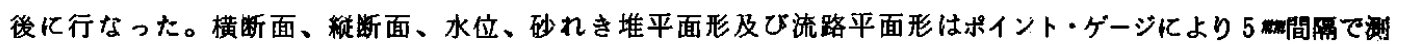

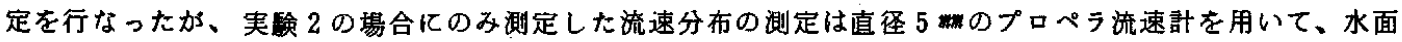
下 7. $5 \mathrm{~mm}$ 、流路愊方向 $2 \mathrm{~cm}$ 間隔、流路軸方向 $2 \mathrm{~m}$ 間隔の各断面において行った。また、蛇行、砂㜛妋砂れき 堆の進行速度の測定は物さしどスップ・ウォッチを用いて行なった。

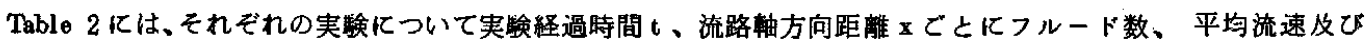
平均水梁の値を示した。ただし、これらの水理量はことでの実冓の性格上、時間と場所に依存して変わるの 
であくまで参考値と考えられるへきものである。

なお、実呀結果の解析に際しては初期流路最上流端の河床面中央を原点とし、それぞれ流下方向を $\mathrm{x}$ 輜、 左岸方向を $\mathrm{y}$ 軸、上方を $\mathrm{z}$ 軸の正とする右手座標系を採用した。また、各実験の経過時間 $\mathrm{t} の$ 時間原点は初 期流路内へ水が流入を開始した時刻とした。

\section{3. 実験結果}

本章では、こてで行なった 4 㮔類の実蛤結果を別々に述べるととにする。

(a) 実 験 1

流路内一水が流入してしばらくすると、流心の水平振動が始まった。とてで流心とは1つの流水横断面内 で流速が最大となる点を意味する（藤芳 $1949 \mathrm{p} 70$ )。時間の経過とともに、流心の水平振動の振幅が徐々に 增大し、Fig. 4(a)の時点で既にての流心の水平振動の振幅が流路幅に達しているために流心直下の河床が洗 掘されるとともに流路側壁の漫食も、流心の軌跡が側壁に当たる部分で顕著となった。したかって、河床は 上から見ると流心の軌跡に治って正弦波状に洗掘されるととになる。ての正弦波状の軌跡に沿って砂漣か鎖

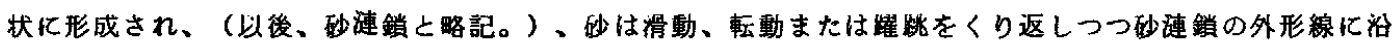
って運ばれると同時に、砂漣鎖全体が徐々に流下方向へ進むととによっても連ばれることがわかった。

河床におりる砂漣銷の形成により、その直上の水面に砂啭銷とほぼ同位相の水面波が形成される。Fig. 4 (b)の時点では流水自体の蛇行はもちろん、流路の平面形状が蛇行状になった。

Fig. 5 Kは $\mathrm{x}=3.7 \mathrm{~m}$ 及び $10.0 \mathrm{~m}$ におりる流路幅と時間 $\mathrm{t}$ との関係を示した。同図には比较のために後出 の実験 2 のデータす合わせてプロットした。Fig. 5 から実跧 1 と央験 2 のいずれの場合にす流路幅は時間と ともに増加することが明ら加になた。また、 $\mathbf{x}=3.7 \mathrm{~m}$ と $\mathrm{x}=10.0 \mathrm{~m}$ の地点における流路幅の增加の仕方 の間には有意の差が設められないか、蛇行蝠は下流の地点ほどその增加率が大きいてとが分かっている。

流路が蛇行形状となると、側岸の各凹面部は良く知られているように時間の経過ととあに徐々に流下方向 へ移動する。Fig. 6 亿各凹面部の頂点の位置と時間との関係を示した。困中の記号 R、Lはそれぞれ右岸、 左岸を意味し、RまたはLに続く数字は各凹面部の頂点の位㯰を示すがれらの番号が若いほど上流の位置 を意味する。Fig.6 加ら、流路凹面部の進行速度は下流のあのほど速いてとが分かる。また、凹面部頂点R4

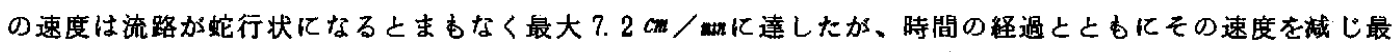
経的速度零となる。ととろが Fig. 6 の四中矢印で示めされているように凹面部頂点L 4、R 3、L 3 及び R 2 のようにその速度が零になるとそのすぐ下流僋に新たな山面部を形成し再び流下方向へ進行するという 事実が観測された。さらにFig. 6 は距解 $\mathrm{x} 、$ 時間 $\mathrm{t}$ 亿かかわらず蛇行長はほほ $2 m$ を保ちながら蛇行形態全 体が下流方向へ進むととも示している。

Fig. 7 亿は距踓 $\mathrm{x}=3.7 \mathrm{~m}$ での流路横断面形状の時間 $\mathrm{k}$ 亿伴なう変化を示した。Fig.7(b)では流心が流路 中央部にあったものが、(c)では右岸側へ移動し、さらに(d)、(e)及びf)では、左岸側に流心があるすのの、断 面形状に数本の明確な裂が認められる。この結果、流心の位置が時間 $\mathbf{t}$ ととあに刻々と変化するとと及び時 間 $\mathbf{t}$ が十分に長くなると、流路内流水が網状となることがわかるであろう。

\section{(b) 実 蛤 2}

初期流路内へ水が流入するやいなや、側壁から流水によりえぐられた砂が流路休に斁いた板を覆いつくす。

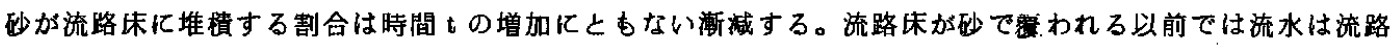
内を直線的に流下し、流水の蛇行は認められな加った。ところで、とのように流路休が完全に仯で覆いつく されてしまえば、この流路の境界条件は実駼 1 のそれと同様になるので、以後の流水の挙動、砂の浸食、輸 送及び堆棈の過程は実呀 1 の場合と極めて似かよったものとなったが同時に次のような相違点が諗められた。 Fig. 5 から、実検 2 のよう飞流路佅に板を敷いた場合のほうが流路幅の増加率及び渐近流路幅とも流路休に 


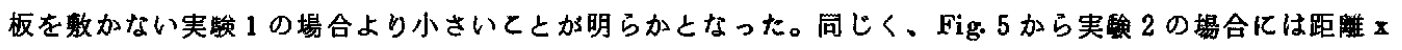
$=2 m$ の場合を徐いて、距離 $\mathrm{x}$ にかかわらず流路幅がほほ同じ率で增加していくととがわかった。このとと

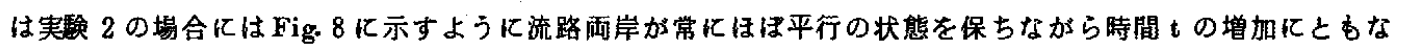
ってその距離を拡げていくととを意味する。さらにFig. 4 (b)と Fig. 8 の流路平面形状を比較すると、実検 2

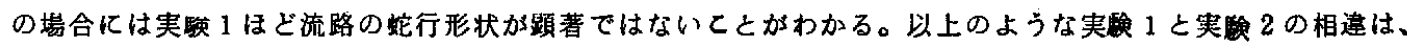
河休に堆棈している砂層厚の差に起因するととは明白である。なお、Fig. 5 で距離 $\mathrm{x}=2 \mathrm{~m}$ における流路楅 の増加の壮方が他と翼なるのは、流路上流端の影唡によるものと考えられる。

Fig.9亿は距踓 $\mathbf{x}=6$ mでの断面流速分布を、またFig.10には同地点での流路断面形状を示した。Fig. 9 (a)と Fig. 10(b)、Fig.9(b)と Fig. 10(c)をそれぞれ比較すると、流速が極大となる位置と河休の洗掘部とが良 い対応を示しているととがわかるであろう。

\section{(c) 実 蛤 3}

初期流路内へ水が流入するとますなく、流路床にFig.11(a)に示したような仯軏銷が形成された。Fig.11 (a)で小判型の部分は個々の砂漣の頂部を示す。また、Fig.11(b)は、河床に砂硨鎖が形成され、水面にてれと ほほ同位相の波が形成されている状況を示す写真である。

河休の砂は、主として流路中央部の砂漣鎖の外形線に治って転動、滑動あるいは躍眺をくり返しなから流 下方向へ輸送されると同時に、砂漣銷全体が下流へ移動するととにより輸送される。例えば時間 $\mathbf{t}=210$ i

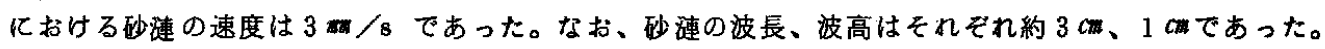

流路内の流水の挙動に関しては、流心の蛇行は顕著には証められなかったものの、流水全体が横摄動をし たために、Fig.11(a)に示したように側壁衣面には波形の水際線を観祭するととができた。

また、Fig.11(a)に示したような砂涷銷は常に流路全体にわたって形成されているわけではなく、笑如として 流路のある区間、ある期間、平滑化されることがあることも明らかになった。

\section{(d) 実 験 4}

初期流路内へ水が流入するとますなく、流心の水平振動が観澌された。

本実臨と実験 3 との間の境界条件の類似性にもかかわらず、両実蛤の河床波の形態が著しく異なる。

Fig. 12 は時間 $\mathrm{t}=96 \sin$ ごろの流路休に形成された砂れき堆の平面形状と主要な流れの概略の軌跡を示した。

但し、ここでは流路最上流端で砂を補給していないので、流路上流部の河床が洗㧐低下する範囲での砂れ き堆の形は不整一なものとなった。

砂旌鎖はFig. 12 の主流の軌跡に沿って主として形成され、副流は砂れき堆の外形線をきわだたせるように 砂を浸食するととがわかった。

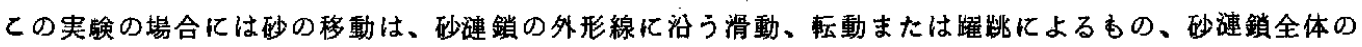
移動によるもの、副流軌跡に沿う滑動または転動によるものに加えて、砂れき堆全体の流下方问への移動に

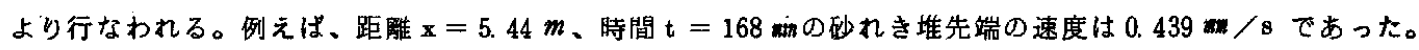

\section{4. 議諭}

著者らは直線流路が蛇行流路へと変形していく前触れ（Precursor）として流水蛇行をとらえている。 換言すれば流水の蛇行素因と流路のそれとの間には本兵的な相違は存在しないものと考えている。そとで、 前章に示した実験結果を流水蛇行と流路境界条件との関連で考察を加えることにする。実蛤 2 の場合で、流

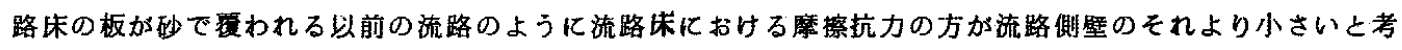
えられる流路境界をもつ流路内の流水は蛇行をしるいで真直ぐに流下するのに対して、実跧 3 及び 4 の場合 の上うに流路休における摩擦抗力の方が流路側壁のそれより大きいと考えられる流路内の流水は蛇行をする 
ととが明らかとなった。なお、実験 1 の場合には流路壁が全て砂でできているので他の 3 つの実験のように 流路境界の流路幅方向への相違はないが、流路壁面の摩 擦抗力の流路幅方向への分布が、流路境界以外の効 果たとえば流路断面形、流路内の流速分布、流路壁構成材料等により、実験 3 及び 4 の分布と同様になるた めに流水の蛇行が起こったものと予想される。

木下（1957. p5 )はここでの実験 3 及び 4 と同様な実験を行ない、河休波の形態が流路幅に対する水深の比 d/w の值により異なるてとを指摘している。すなわち、流路休を構成する砂の粒径により粠なるとしながらあ、 $\mathrm{d} / \mathrm{w}=0.1 \sim 0.05$ 程度では砂れき堆が形成されるのに対して、 $\mathrm{d} / \mathrm{w}>0.1$ の範井では砂堆または砂漣が形成 されると述べている。事実、ててでの実験においてあ $\mathrm{d} / \mathrm{w} \div 0.25$ である実験 3 の場合には砂連が形成され、 $\mathrm{d} / \mathrm{w} \div 0.023$ である実験 4 の場合には砂れき堆が形成された。一方、てのような河床波の形態の差をつルード 数の違いに帰着する見方むできよう。Table 2 から、実験 3 の場合のフルード数は 1 以下であるのに対して、実 験 4 の場合のフルード数は 1 以上である事実に注目すれば、常流の場合には砂漣が形成され、射流の場合に は、砂れき堆が形成されるのであろうという予測も可能であるが、てれに関して林（1970 p21)は木下によ る比重が比較的に小さい石灰粒子を用いたフルード数が 1 よりかなり小さい場合の実験結果を引用し砂れき 堆の形成はフルード数には依存しないてとを示唆している。

以上のてとから、ててでの実験 3 あるいは実験 4 のような境界をすつ流路の河佅形態は木下（1957）の指 摘のように流路幅に対する水喍の比が支配的に影響するあのと考えられる。

5. 結 論

流路内の流水挙動、流路形態及び河休形態は流路の境界条件に依存して変わるととが明らかになった。 また、流路休におりる摩擦抗力の方が流路側壁のそれより小さいと考れられる流路境界を有する流路内の 流水は蛇行しないが、逆に流路休における摩擦抗力の方が流路側壁のそれより大きいと考えられる流路内の 流水は蛇行するてとが明らかとなった。

6. 謝 辞

故足立昭平氏は著者らの一人（中川）に蛇行研究の端緒を与えられたのみならず、本研究の遂行にあた り、幾多の有益な助言を与えられた。

また、本実験は名古屋大学土木工学科水理実験室において行われたものであるが、その間、名古屋大学・ 高木不折氏, 豊橋技術科学大学・中村俊六氏, 大同工業大学・久保田稳氏及び当時の名古屋大学学生・ 真新哲朗君に種々の援助をいただいた。ここに付記し、謝辞とする。

参 考 文 觔

1）木下良作：河休に扰りる砂鿬堆の形成について、土木学会論文集、第 42 号、1-21（1957）。

2) 中川武夫・中川俊六、真新哲朗：蛇行の発生と、流路形態に関する実験的研究。土木学会中央支部研 究発表会講演概要集、76-77（1981）。

3 ）藤芳義男：河川の蛇行と災害（河川蛇行論）、佐々木図書出版、東京（1949）。

4) 林泰造：河川蛇行論、土木学会水理委員会、水工学シリーズ70-16（1970）。

5) Adachi. S. : A Theory of Stability of S treams. Proc. IAHR, 1, $338-344$ ( 1967 )。

6) Nakato. T. :Model Studies of Bed Roughness in Alluvial Streams. M. Sc. Thesis. Department of Civil Engineering, Nagoya University(1968). 


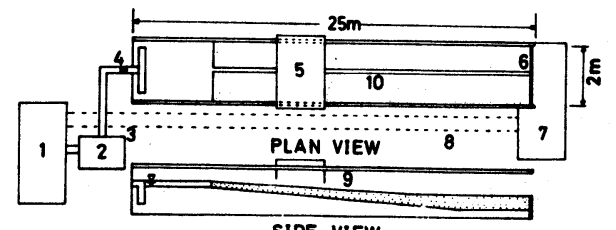

Fig.1 Schematic diagram of meandering flume. 1; low tank,2; high tank,3;pump,4;flow meter, 5; scraper,6; weir,7; sand poo1,8; return channel, 9; rail,10; channel.

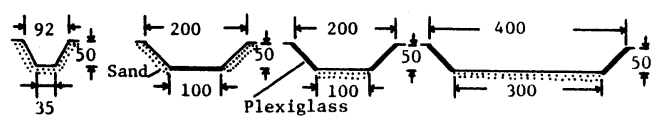
Exp. 4

$\begin{array}{ccc}\text { Exp.1 Exp.2 Exp.3 } & \text { Exp.4 } \\ \text { Fig.3 Cross sections, dimensions and boun- }\end{array}$ dary conditions for each intial channel.

(units:mm)
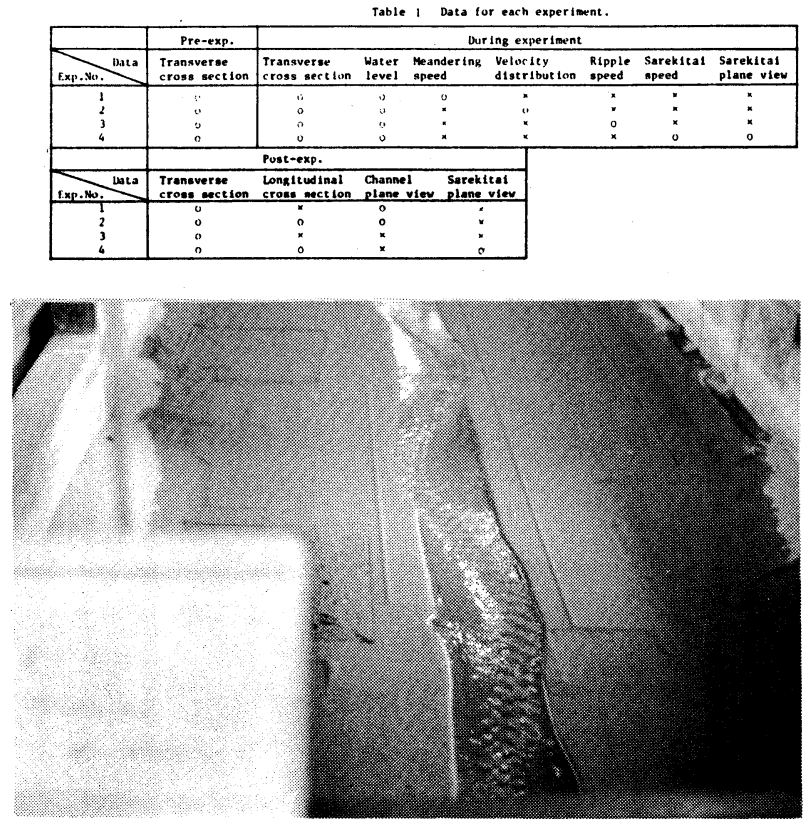

Fig.4(a) Meandering of water stream centre. $(t=91$ min.)

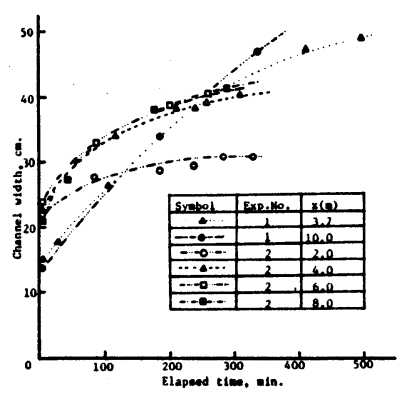

Fig.5 Channel width vs. elapsed time.

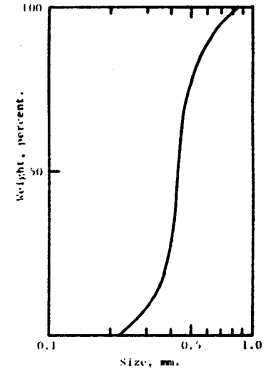

Fig.2 Size distribution of sand(after Nakato 1968).
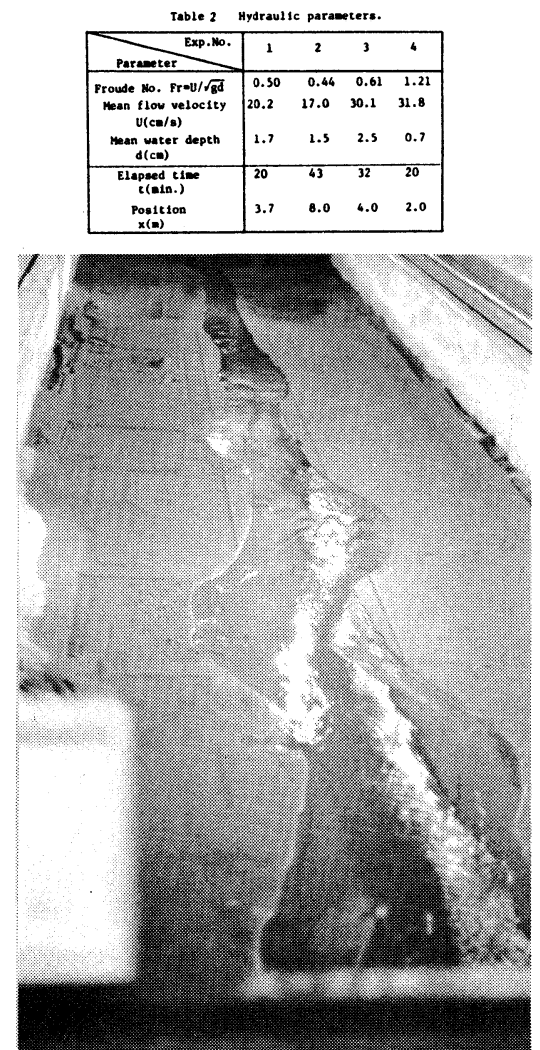

Fig.4(b) Meandering of a sand channe1

$(t=305$ min. $)$

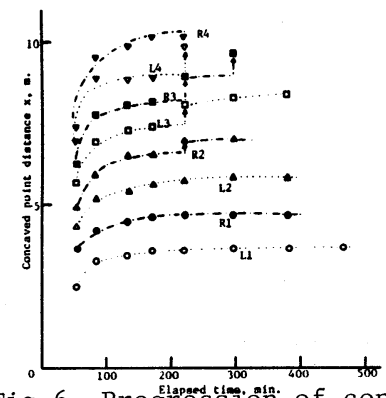

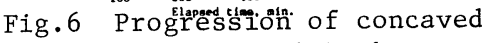
points at a channel bank. 


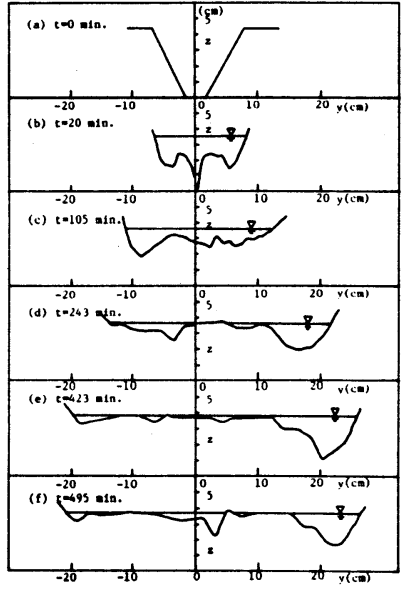

Fig.7 Development of cross section for a sand channel. $(\mathrm{x}=3.7 \mathrm{~m})$

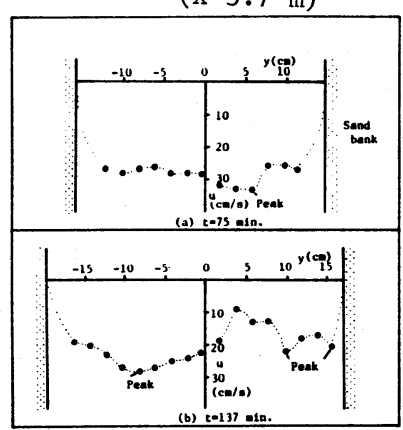

Fig. 9 Velocity distribution at a channel cross section composing of sand except bed initially.

$(\mathrm{x}=6.0 \mathrm{~m}$ and $7.5 \mathrm{~mm}$ below water surface.)

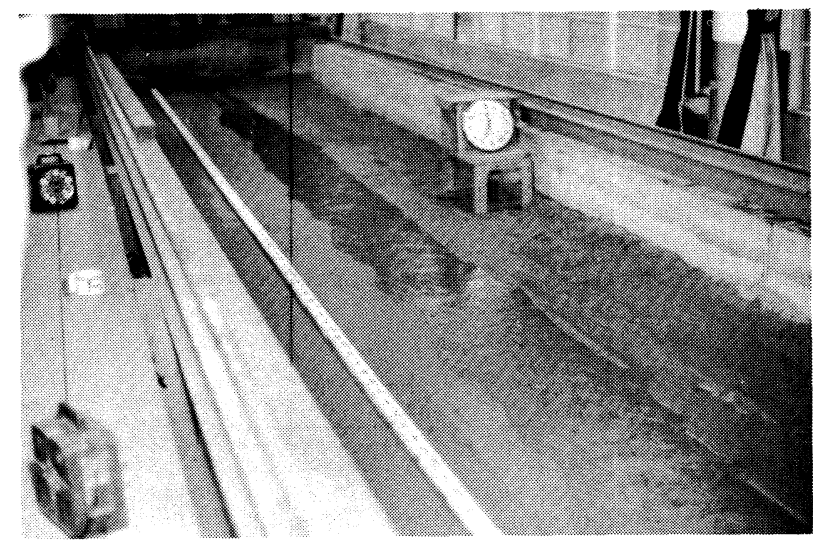

Fig.8 Pattern of sand channel with solid bed initially. $\quad(t=300$ min. $)$

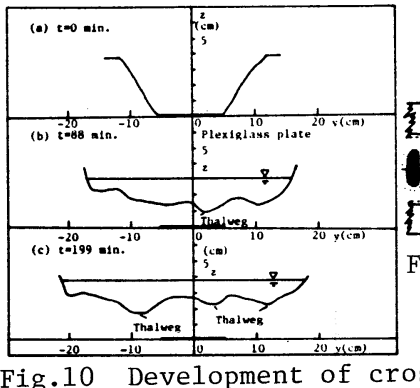

Fig.10 Development of cross section for a channel composing of sand except bed initially. $(x=6.0 \mathrm{~m})$.

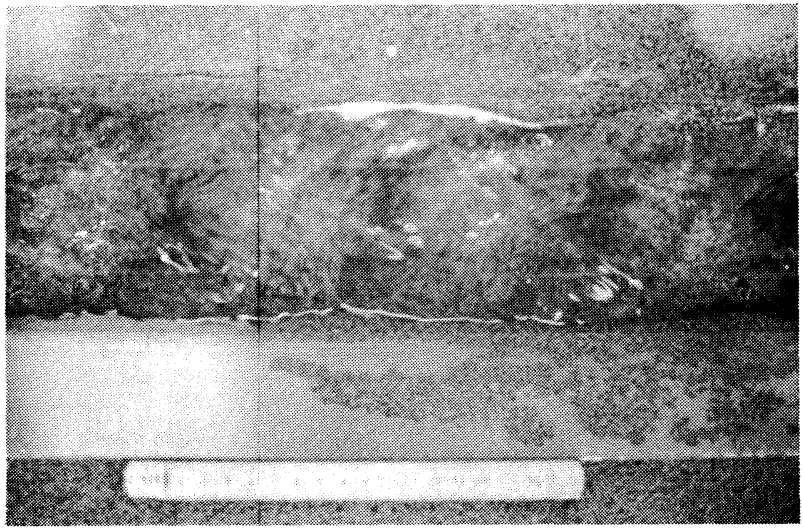

Fig.11(b) Surface waves over sand ripple trains.

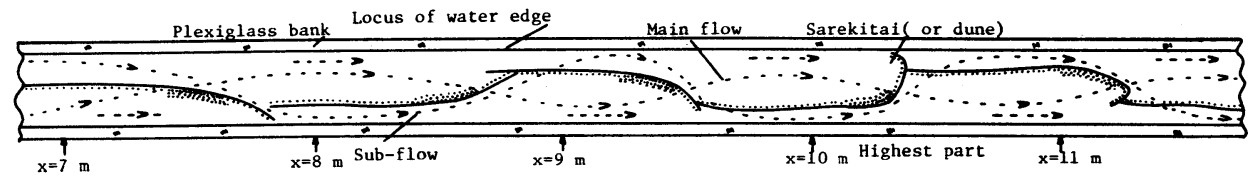

Fig.12 Formation of 'Sarekitai'(or dune) on a sand bed with solid bank. ( $t=96$ min.) 